Vol. 6 (1997): 269-281.

\title{
Effect of nitrogen fertilization, grass species and cultivar on sod production on Valkeasuo peat bog - a case study
}

Perttu Virkajärvi

Agricultural Research Centre of Finland, North Savo Research Station, FIN-71750 Maaninka, Finland, e-mail: perttu.virkajarvi@mtt.fi

Harri Huhta

Agricultural Research Centre of Finland, Research Station for Ecological Agriculture, FIN-51900 Juva, Finland

Hannu Tuuri

Agricultural Research Centre of Finland, Data and Information Services, FIN-31600 Jokioinen, Finland

\begin{abstract}
As part of a research project concerning the agricultural utilization of cut-away peat bogs, a sod production experiment was conducted at Valkeasuo, Tohmajärvi, in 1990-1993. The aim of the experiment was to study the effect of nitrogen and choice of cultivar on sod production and sod quality on peat bogs. The $\mathrm{N}$ fertilization rates were 50,100 and $150 \mathrm{~kg} \mathrm{ha}^{-1}$. The Poa pratensis cultivars were 'Conni', 'Cynthia', 'Haga' and 'Julia', the Festuca rubra cultivars were 'Center', 'Juliska', 'Koket' and 'Näpsä' and the Agrostis capillaris cultivar was 'Rasti'. Two mixtures of $P$. pratensis/F. rubra and one of A. capillaris/F. rubra imitated commercial sod products.

Increasing of $\mathrm{N}$ fertilization from $50 \mathrm{~kg}$ up to $150 \mathrm{~kg} \mathrm{ha}^{-1}$ a had positive effect on general the quality of sod as well as on the green cover before and after transplanting. It increased the thatch formation. The positive effect of $\mathrm{N}$ on the number of tillers and green cover in the year following transplanting was dependent on the species and the cultivar. Species and cultivar affected all measured variables excluding thatch formation. Generally, the $P$. pratensis cultivars tested suited better for sod production than cultivars of $F$. rubra, but there were clear differences between cultivars within species as well. Although the soil was infertile, the contents of $\mathrm{Ca}, \mathrm{K}, \mathrm{Mg}, \mathrm{P}, \mathrm{Cu}, \mathrm{Fe}, \mathrm{Mn}, \mathrm{Mo}$ and $\mathrm{Zn}$ in the herbage samples were within normal range. The botanical purity was high, which supports the hypothesis that the absence of seed bank of weeds on peat bogs immediately after harvesting the peat can be utilized.
\end{abstract}

Key words: Agrostis capillaris, Festuca rubra, lawns, peat soils, Poa pratensis

\section{Introduction}

The total area of mires in peat production is about 50.000 hectares in Finland. Nearly 2.000 hec- tares of that area becomes cut-away every year. The after use of the cut-away peat bogs has been an important question since the 1980's, and several possibilities instead of abandoning or restoring mires have been proposed (Heikkilä 1990).

(C) Agricultural and Food Science in Finland

Manuscript received February 1997 
Virkajärvi, P. et al. Effect of fertilization, grass species and cultivar on sod production

As part of a research project concerning the agricultural utilisation of cut-away peat bogs, a sod production experiment was conducted at Valkeasuo, Tohmajärvi (62\%20'N, 30\%15'E) in 1990-1993.

In sod production the requirements for the soil are high. However, peat bogs do have some advantages which make them potential for sod production. First, immediately after the peat has been harvested, the soil is practically free from weeds and soil-borne diseases. For example, Poa annua, which is generally a difficult weed in lawns, has lowered in some occasions the quality of delivered sod on sport turfs (Erlund 1991, Lahdensuo 1993). Second, some bog areas are practically free from stones, which is a definite requirement for sod production. On the other hand, pieces of undecomposed timber in the soil may prevent sod production on some areas, since they damage the sod during the lifting process. Third, the paddocks on peat bogs are often large and flat. The infertility of the peat bogs must not be a disadvantage: if fertilizing and irrigation are performed properly, the roots will remain at the top layer of the soil. When the sod is then moved to a more fertile substrate, it will root effectively because the roots grow rapidly into the new, fertile subsoil.

The aim of the experiment was to study the effect of nitrogen and choice of cultivar on sod production and sod quality on peat bogs. Nitrogen is known to affect many turf quality parameters, e.g. growth pattern, density, colour, coldhardiness and botanical composition of the turf community (Beard 1973). High amounts of nitrogen will accelerate the growth of the tillers at the expense of root growth and thus increase the need of mowing and litter production (Turner and Hummel 1992). On the other hand, nitrogen fertilization must be adequate, since nitrogen deficiency should neither restrict the density of tillers nor impair the colour of the turf.

In Finnish trials with Poa pratensis and Festuca rubra, it has been shown that cultivar has a major effect on the lawn quality (Huusela-Veistola et al. 1991, Niemeläinen and Huusela-Veistola 1991). Since peat bogs are rather difficult areas with reference to overwintering conditions, only high- or medium-quality cultivars of $P$. pratensis, Festuca rubra ssp. rubra, Festuca rubra ssp. communtata and Agrostis capillaris were chosen. In addition to pure cultivars, also mixtures of P. pratensis and Festuca as well as A. capillaris and Festuca were sown to imitate commercial sod products.

\section{Material and methods}

\section{Establishing the experiment}

On the study area, the top soil was coarse sand, the proportion of humus being $15 \pm 6.8 \%$ (mean $\pm \mathrm{sd})$. The area was limed with 7.3 tons per hectare limestone containing $\mathrm{Mg}$ and fertilized with a compound fertilizer $(30 \mathrm{~kg} \mathrm{~N}, 21 \mathrm{~kg} \mathrm{P}, 42 \mathrm{~kg}$ $\mathrm{K} \mathrm{ha}^{-1}$ ). Soil analyses after lifting the sod showed the following concentrations of soluble nutrients $\left(\mathrm{mg} \mathrm{l}^{-1}\right)$ : $\mathrm{Ca}$ 933, K 39, $\mathrm{Mg} 56$ and $\mathrm{P} 1.1$. The $\mathrm{pH}$ $\left(\mathrm{H}_{2} \mathrm{O}\right)$ was 5.4 . The plot size was $300 * 45 \mathrm{~cm}$ with $25 \mathrm{~cm}$ zones at both ends of the plots for sampling procedures. The plots were sown by hand on 24 August 1990. The experiment had three replicates. The treatments are presented in Table 1.

The plots were fertilized with $10 \mathrm{~kg} \mathrm{~N}, 50 \mathrm{~kg}$ $\mathrm{P}$ and $90 \mathrm{~kg} \mathrm{~K} \mathrm{ha}^{-1}$ (as compound fertilizer including trace elements) in May 1991 and 1992. One half of the nitrogen doses was applied simultaneously while the other half was applied at the end of June. The lawn was mown to the height of 3-4 cm twice a week during early summer and once a week during late summer. In the autumn 1990 and 1991, Quintozene (13-16 kg $\mathrm{ha}^{-1}$ Avicol) was sprayed against fungi (e.g. Fusarium nivale, Typhula sp. Sclerotinia borealis) to prevent overwintering damage.

\section{Observations and measurements}

The establishment was estimated on the basis of the green cover $(0-100 \%)$. In the first growing year the green cover was estimated five times 


\section{AGRICULTURAL AND FOOD SCIENCE IN FINLAND}

Vol. 6 (1997): 269-281.

and in the lifting year and the following year once a week. The shoot density was counted from core samples $(\varnothing 5.0 \mathrm{~cm})$, two per plot in 1991 and 1992. The root mass was determined from subplot treatments $2,5,8$ and 10 by taking core samples $(\varnothing 7.2 \mathrm{~cm})$ to the depth of $12 \mathrm{~cm}$. The samples were cut horizontally into five layers: $0-2.0$, $2.0-4.5,4.5-7.0,7.0-9.5$ and $9.5-12.0 \mathrm{~cm}$. The samples were stored at a temperature of -1 to $0^{\circ} \mathrm{C}$ and taken to room temperature for 24 hours before washing on a sieve. Subsequently, they were oven-dried $\left(24\right.$ hours at $\left.100^{\circ} \mathrm{C}\right)$.

Before lifting, the quality of the sod was estimated as follows:

$\begin{array}{ll}\text { Characteristic } & \text { Scale } \\ \text { Colour } & 0-5(0=\text { defect in colour }) \\ \text { Density } & 0-5(0=\text { sparse }) \\ \text { Uniformity } & 0-5(0=\text { incoherent }) \\ \text { Weeds } & 0-1(0=\text { weeds disturb })\end{array}$

The sum variable of sod quality (maximum 16 points) was taken as a continuous variable.

Samples of roots and tillers were taken again on 11 August 1992 before lifting. A bulk sample of herbage of P. pratensis and F. rubra was cut to the height of $2 \mathrm{~cm}$ to estimate possible nutrient deficiency. N, P, K, Ca, Mg, Cu, Fe, Mn, Mo and $\mathrm{Zn}$ were analysed from the samples in the Central Laboratory, Agricultural Research Centre, Jokioinen.

$250 * 45 \mathrm{~cm}^{2}$ pieces of the sod were lifted with the machinery of Karjalan Nurmi Ltd on $14 \mathrm{Au}$ gust 1992. A $150 * 45 \mathrm{~cm}^{2}$ piece of each plot was assembled in the same order as before on mineral soil (pH 6.1, Ca 1240, K 40, P 9.9 mg/l). The area was fertilized ( $30 \mathrm{~kg} \mathrm{~N}, 21 \mathrm{~kg} \mathrm{P}, 42 \mathrm{~kg} \mathrm{~K}$ $\left.\mathrm{ha}^{-1}\right)$ and well irrigated before transplanting. The trial was carefully rolled after assembling.

The handling tolerance of sod was measured as tearing force from three samples $(21 * 21 \mathrm{~cm})$ per plot as described by Shildrick (1982). The rooting of the sod was evaluated five weeks after transplanting by core samples $(\varnothing 5.0 \mathrm{~cm})$, two per plot, and given values $0-5(0=$ not rooted at all, sod loose from subsoil, no new roots visible; 5 = sod well rooted, removing from subsoil difficult, new roots abundant in subsoil).
Table 1. Treatments.

Main plot: Nitrogen fertilization $\left(\mathrm{kg} \mathrm{ha}^{-1}\right.$ year-1).

1: 50

2: 100

3: 150

Subplot: species, cultivar or mixture

\begin{tabular}{|c|c|c|}
\hline No Species & Cultivar & $\begin{array}{l}\text { Seed rate } \\
\mathrm{g} \mathrm{m}^{-2}\end{array}$ \\
\hline 1 P. pratensis & Conni & 10 \\
\hline $2 \quad "$ & Cynthia & $"$ \\
\hline $3 \quad "$ & Haga & 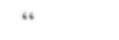 \\
\hline $4 \quad " *$ & Julia & $"$ \\
\hline 5 A. capillaris & Rasti & 8 \\
\hline $6 F$ r. communtata & Center & 20 \\
\hline 7 F. r. rubra & Juliska & " \\
\hline $8 F$. r. communtata & Koket & “ \\
\hline 9 F.r. rubra & Näpsä & “ \\
\hline \multirow[t]{2}{*}{10 Mixture $1^{1)}$} & Center/Juliska// & \\
\hline & Conni/Julia/Haga & 16 \\
\hline \multirow[t]{2}{*}{11 Mixture $2^{1) 3 \text { ) }}$} & Center/Wilma// & \\
\hline & Conni/Julia/Cynthia & 16 \\
\hline 12 Mixture $3^{2)}$ & Rasti//Center & 10 \\
\hline
\end{tabular}

1) $20 \%$ each cultivar

2) $80 \%$ A. capillaris, $20 \%$ F rubra

3) $\mathrm{Wilma}=$ F.r.c.

The botanical composition of the plots was observed on 28 June 1993 with a point quadrat, 100 points per plot. The observations were divided into six classes: $F$. rubra, $P$. pratensis, $A$. capillaris, other monocotyledons, dicotyledons and gaps.

\section{Statistical Methods}

The data was analysed mainly by the analysis of variance according to the split-plot design. Replication was considered a random effect whereas $\mathrm{N}$ fertilization as well as species/cultivar were considered fixed effects. $\mathrm{N}$ fertilization was analyzed as main plot factor and species/cultivar as the subplot factor. Analyses were performed by means of the SAS statistical package. MIXED (SAS 1992) and GLM (SAS 1991) procedures were used. 


\section{AGRICULTURAL AND FOOD SCIENCE IN FINLAND}

\section{Virkajärvi, P. et al. Effect of fertilization, grass species and cultivar on sod production}

In analysing root mass the years and depths were analysed as repeated-measures factors in the same split-plot experiment mentioned above. The multivariate approach was used in the analysis and it was performed by means of the GLM procedure of the SAS. After this the most important layer $(0-2 \mathrm{~cm})$, was examined separately. In these analyses year was the only repeatedmeasures factor.

Green cover data for the lifting year (1992) and the following year (1993) were analysed separately. In both years the growing season was divided into three periods. The green cover values for each period were already means of six weekly observations done in each period. Thus the repeated-measure factor, period, had three levels. Green cover was analysed using the multivariate analysis of variance with period as a repeated-measures factor in the split-plot experiment. In the sequel, periods were examined separately because the effects of nitrogen fertilization and species were different in different periods.

Rooting ability, which is an ordinal-scaled variable, was analysed using a split-plot, nonparametric analogue. The analysis was based on recommendations by Koch et al. (Koch 1970, Koch et al. 1980) regarding the non-parametric approach for repeated measurements. All effects were tested separately using the Friedman test and by means of StatXact 3 for WINDOWS software (CYTEL Software Corporation 1995). The testing of interaction effect between $\mathrm{N}$ fertilization and species/cultivar was divided into three parts because of the three levels of $\mathrm{N}$ fertilization (main plot factor). Therefore, when the significance of interaction was examined, the number of tests was taken into account by using Bonferoni's approach (Rosenthal and Rosnow 1985 , p. 45). Prior to the analysis, however, the data had to be pooled in several ways to allow tests of various effects. All these modifications were done by means of the SAS.

The botanical composition was examined in the final analysis as a three-compositional factor (sown species, gaps and others). The proportions that describe the botanical compositions sum up to 1 over all botanical types. So, they are obviously not independent. It can therefore be misleading to analyse the data for each botanical type separately. Our strategy for the analyses was to convert the compositions to additive log-ratio compositions, to reformulate the underlying problem in terms of these log-ratio composition and to make use of the multivariate analysis of variance (Aitchison 1986). The GLM procedure of the SAS was used for analyses. Before calculating the log-ratio compositions, $0 \%$ in the botanical composition was assigned $0.1 \%$.

In general, it was not found necassary to examine pairwise differences. However, if multiple-comparison procedures were needed, Tukey's HSD method or t-type contrast examination was used.

Before performing the analysis of variance, accordances of data with the distributional assumptions of the models were checked by diagnostic methods (e.g. Box-Cox diagnostic plots) on what basis some variables were transformed. the germinating percentage was square roottransformed, the Fe content 1/x-transformed, the $\mathrm{Cu}$ and $\mathrm{Mn}$ contents $\log (\mathrm{x})$-transformed and the root mass $\log (1+\mathrm{x})$-transformed.

\section{Results}

Germination and establishment were satisfactory. This was confirmed by the high green cover values in 1991. The weather data are presented in Table 2.

In the lifting year of 1992, the effect of nitrogen on the green cover was different in different periods $(\mathrm{p}=0.030$ for interaction of $\mathrm{N}, \mathrm{SP}$ and Period). Therefore, analyses were carried out by periods. The $\mathrm{N}$ fertilization did not affect the green cover in the spring, but it increased the green cover in midsummer (Table 3 ). However, the magnitude of the effect remained low. After lifting and transplanting the sod the green cover values dropped clearly. This decrease was most sharp with low $\mathrm{N}$ and only slight with high $\mathrm{N}$. No interaction with $\mathrm{N}$ fertilization and cultivar/ 


\section{AGRICULTURAL AND FOOD SCIENCE IN FINLAND}

Vol. 6 (1997): 269-281.

mixture was detected during any period, which indicates that the effect of $\mathrm{N}$ fertilization was almost the same for each species/cultivar.

Species/cultivar played a major role in the green cover values in each period. The ranking order between species/cultivar did change in the course of the season. After transplanting, especially 'Center', 'Koket' and 'Näpsä' had low values, while 'Conni' maintained a high green cover.

The general quality of sod improved by increasing $\mathrm{N}$ fertilization without interaction with species/cultivar (Table 3). Again, there were clear differences between cultivars. Generally, cultivars of $P$. pratensis and A. capillaris 'Rasti' had higher values than $F$. rubra cultivars. The partial rankings (density, colour, uniformity, proportion of weeds) had the same pattern as the sum variable, except disturbance of weeds, which was not affected by $\mathrm{N}$ fertilization.

In the botanical analysis carried out in the summer following transplanting, the mean proportion of gaps was $8 \%$ (SD 9.4\%). The mean proportion of weeds was only $5 \%$ (SD $11 \%$ ) for all species/cultivars and only 2\% (SD 3.3\%) when 'Näpsä' was excluded. 'Näpsä' was a clear exception and it was left out from the analysis of variance. Proportion of sown species, the most important factor in the botanical composition, is described in Table 3. The effect of $\mathrm{N}$ fertilization on the proportion of sown species was not statistically significant. However, there were clear differences between cultivars (also without 'Näpsä'). The proportion of sown species was highest in 'Rasti' and lowest in 'Cynthia' and 'Näpsä', as mentioned above. The low proportion of sown species in 'Näpsä' was mainly due to its low rooting ability. Its proportion was $35 \%$ with $50 \mathrm{~kg} \mathrm{~N}$ and $61 \%$ with $150 \mathrm{~N}$.

Nitrogen did not affect the rooting, but species/cultivar did. 'Näpsä' rooted most poorly while 'Cynthia', 'Haga', 'Julia', 'Koket', Mixture 2 and Mixture 3 were a quite homogeneous, well-rooting group, the rest being intermediate (Table 3).

The effect of species/cultivar on the number of tillers was clear $(p<0.001)$ in 1992. The ef-
Table 2 . Monthly mean temperatures and precipitation sums during growing seasons of 1990-1993 in Tohmajärvi.

\begin{tabular}{|c|c|c|c|c|c|}
\hline & 1990 & 1991 & 1992 & 1993 & $1961-1990$ \\
\hline \multicolumn{6}{|c|}{ Mean temperature, ${ }^{\circ} \mathrm{C}$} \\
\hline May & 7.8 & 7.6 & 9.5 & 11.0 & 8.6 \\
\hline June & 12.2 & 13.3 & 14.5 & 10.7 & 14.0 \\
\hline July & 15.1 & 16.1 & 14.8 & 15.2 & 15.9 \\
\hline August & 13.7 & 14.5 & 13.3 & 12.8 & 13.5 \\
\hline September & 6.8 & 8.0 & 11.3 & 4.2 & 8.3 \\
\hline \multicolumn{6}{|c|}{ Precipitation, mm } \\
\hline May & 34 & 41 & 18 & 23 & 36 \\
\hline June & 28 & 117 & 40 & 89 & 57 \\
\hline July & 82 & 124 & 54 & 143 & 70 \\
\hline August & 56 & 130 & 105 & 131 & 80 \\
\hline September & 17 & 80 & 46 & 44 & 65 \\
\hline
\end{tabular}

fect of $\mathrm{N}$ was dependent on the cultivar $(\mathrm{N} * \mathrm{SP}$ interaction, $\mathrm{p}=0.032$ ). On average, the number of tillers increased slightly with increasing $\mathrm{N}$ fertilization: 41100,48900 and 54600 tillers $\mathrm{m}^{-2}$ with 50,100 and $150 \mathrm{~kg} \mathrm{~N} \mathrm{ha}^{-1}$, respectively ( $p=0.008$, SEM 1236). The effect of subplot was not only due to different species but there were clear differences between cultivars as well. The highest density was observed in 'Rasti', 77100 tillers $\mathrm{m}^{-2}$ with $150 \mathrm{~kg} \mathrm{ha}^{-1} \mathrm{~N}$, and lowest in 'Haga', 21900 tillers $\mathrm{m}^{-2}$ with $50 \mathrm{~kg} \mathrm{ha}^{-1} \mathrm{~N}$. Among $F$. rubra, the highest observed density was found in 'Center' plots, 68500 tillers $\mathrm{m}^{-2}$ with $150 \mathrm{~kg} \mathrm{ha}^{-1} \mathrm{~N}$.

Nitrogen fertilization increased the thatch formation $(\mathrm{p}=0.047)$. The thicknesses of the thatch layers were 12.4, 14.7 and $18.7 \mathrm{~mm}$ (SEM $0.65 \mathrm{~mm}$ ) with 50,100 and $150 \mathrm{~kg} \mathrm{~N} \mathrm{ha}^{-1}$, respectively.

The effect of $\mathrm{N}$ fertilization on the tearing force was dependent on the species/cultivar (Table 4). Nitrogen could either increase or decrease the tearing force. However, the magnitude of the effect was not high, ca $\pm 10 \mathrm{~kg}$ at the most. Species/cultivar had a much greater effect: the samples of 'Conni' tolerated over twice the force that 'Rasti' tolerated. In addition to 'Conni', 'Cyn- 


\section{AGRICULTURAL AND FOOD SCIENCE IN FINLAND}

Virkajärvi, P. et al. Effect of fertilization, grass species and cultivar on sod production

Table 3. Effect of nitrogen fertilization and species/cultivar on the green cover, quality, rooting and proportion of sown species of sod. Main effect means, standard errors of means (SEM) and significances of $\mathrm{F}$ values in the analysis of variance (p values) are presented.

\begin{tabular}{|c|c|c|c|c|c|c|}
\hline & \multicolumn{3}{|c|}{ Green cover \% } & \multirow[t]{2}{*}{ Quality ${ }^{1}$} & \multirow{2}{*}{$\begin{array}{l}\text { Rooting } \\
\text { (Ranked }^{2} \text { ) }\end{array}$} & \multirow{2}{*}{$\begin{array}{l}\text { Proportion of } \\
\text { sown species } \\
\%\end{array}$} \\
\hline & Spring & Summer & Transplanted & & & \\
\hline \multicolumn{7}{|c|}{ Nitrogen fertilization $(N)$} \\
\hline N 50 & 38 & 75 & 53 & 5.8 & $2.0(1.3)$ & 79 \\
\hline N 100 & 39 & 82 & 67 & 9.2 & $2.4(2.0)$ & 87 \\
\hline N 150 & 40 & 85 & 80 & 11.3 & $2.7(2.6)$ & 92 \\
\hline SEM & 1.1 & 0.6 & 1.5 & 0.34 & - & - \\
\hline \multicolumn{7}{|c|}{ Species/cultivar (SP) } \\
\hline Conni & 38 & 89 & 80 & 11.7 & $2.2(5.6)$ & 95 \\
\hline Cynthia & 40 & 83 & 64 & 10.2 & $2.9(8.2)$ & 77 \\
\hline Haga & 53 & 85 & 67 & 9.6 & $2.8(8.3)$ & 89 \\
\hline Julia & 46 & 84 & 66 & 9.5 & $2.7(8.1)$ & 89 \\
\hline Rasti & 31 & 91 & 67 & 10.9 & $2.3(6.3)$ & 96 \\
\hline Center & 36 & 73 & 59 & 5.5 & $2.1(5.3)$ & 85 \\
\hline Juliska & 37 & 75 & 65 & 7.4 & $2.1(4.6)$ & 90 \\
\hline Koket & 37 & 73 & 61 & 7.3 & $2.7(8.2)$ & 83 \\
\hline Näpsä & 32 & 80 & 62 & 8.5 & $0.7(1.2)$ & 49 \\
\hline Mixture 1 & 41 & 79 & 68 & 7.9 & $2.1(5.0)$ & 94 \\
\hline Mixture 2 & 39 & 78 & 69 & 8.3 & $2.9(8.8)$ & 93 \\
\hline Mixture 3 & 38 & 79 & 68 & 8.4 & $2.8(8.4)$ & 93 \\
\hline \multirow[t]{2}{*}{ SEM } & 1.1 & 1.1 & 2.0 & 0.58 & - & - \\
\hline & \multicolumn{6}{|c|}{$P$ values } \\
\hline \multicolumn{7}{|c|}{ Source of variation } \\
\hline $\mathrm{N}$ & 0.39 & $<0.001$ & $<0.001$ & $<0.001$ & 0.36 & 0.17 \\
\hline SP & $<0.001$ & $<0.001$ & $<0.001$ & $<0.001$ & $<0.001$ & $<0.001$ \\
\hline $\mathrm{N} * \mathrm{SP}$ & 0.12 & 0.65 & 0.20 & 0.42 & $\begin{array}{l}0.25^{4} \\
0.19^{5} \\
0.06^{6}\end{array}$ & 0.24 \\
\hline
\end{tabular}

\footnotetext{
1) Sum variable consisting of colour, density, uniformity and disturbance of weeds. Maximum points 16.

2) Rooting: original values with 0-5 scale and means of rankings in parentheses, best $\mathrm{N}$ level in each case receives 3 points and best cultivar 12 points.

${ }^{3)}$ Only means of the most important compositional factor (proportion of sown species) are presented. The p values are results from the analysis of the botanical composition. Näpsä is excluded from the analysis of variance.

4)-6) Rooting was analysed using a split-plot non-parametric analogue, where testing of interaction was divided into three parts. So three p values are presented for interaction effect. ${ }^{4)}$ for $\mathrm{N}$ levels 50 vs 100 , 5) 50 vs 150 and $^{6)} 100$ vs 150 .
}

thia', 'Juliska' and Mixtures 1 and 2 tolerated high tearing forces at all $\mathrm{N}$ levels.

Below-ground samples were collected from 'Cynthia', 'Koket', 'Rasti' and Mixture 1 in 1991 and 1992. Since no anatomical separation into roots and other organs was done, the term 'below-ground biomass' is more precise than root mass. It increased from 1991 to 1992 but at different rates at different depths and for different cultivars (year, depth and cultivar interaction, 
Vol. 6 (1997): 269-281.

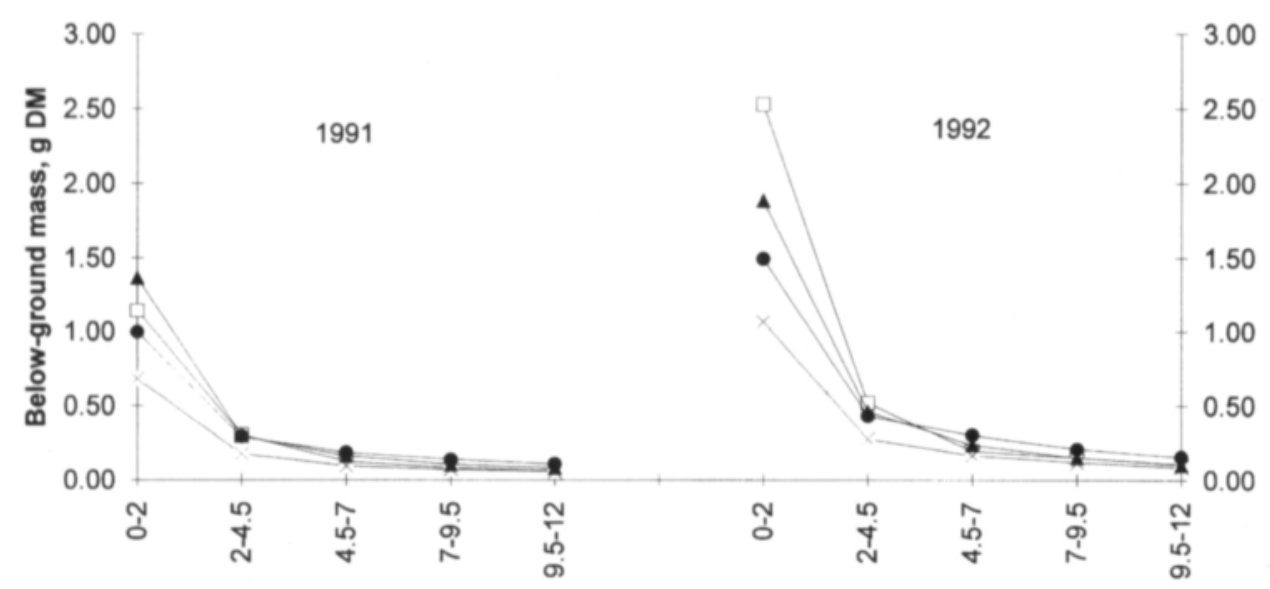

Depth, cm

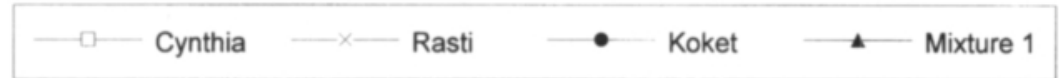

Fig. 1. Below-ground biomass (original scale) of 'Cynthia', 'Rasti', 'Koket' and Mixture 1 on average in 1991 and 1992 at five different sampling layers. Cross-section area of core sample was $40.7 \mathrm{~cm}^{2}$.

$\mathrm{p}=0.015$; Figure 1). Since the uppermost layer $(0-2 \mathrm{~cm})$ is the most important in respect to sod production, it was analysed more carefully. Some $65 \%$ of the detected biomass was located in this layer. The differences between cultivars were greater in this layer than in the deeper layers. By harvest, the biomass of 'Cynthia' was the highest, those of 'Koket' and Mixture 1 were intermediate, and 'Rasti' had the lowest biomass. Also the increase of the biomass during the second growing season was greatest in 'Cynthia'. Mixture 1 and 'Koket' did not differ in respect to biomass or biomass increase. 'Rasti' had a lower biomass by the time of lifting although the increment was of the same magnitude as that of 'Koket' or Mixture 1. This means that the differences between cultivars, except for 'Cynthia', were established mainly during the first season ( all differencies found at level $\mathrm{p}<0.05$ ). Nitrogen had only a tendency to decrease the belowground biomass of the uppermost layer $(\mathrm{p}=0.10)$.

Increasing nitrogen fertilization increased the $\mathrm{N}$ and $\mathrm{P}$ concentrations and decreased the $\mathrm{Mn}$ and Mo concentrations (Table 5). The $\mathrm{Ca}, \mathrm{P}, \mathrm{Fe}$, and Mn concentrations were higher in Festuca than in Poa, but the $\mathrm{Mg}$ and Mo concentrations
Table 4. Interaction between $\mathrm{N}$ fertilization and species/ cultivar on the tearing force $(\mathrm{kg})$ of sod samples (width $21 \mathrm{~cm}$ ). Species means ( 3 subsamples and 3 replicates) within $\mathrm{N}$ fertilization levels, standard error of means (SEM) and significance of $\mathrm{F}$ values in the analysis of variance.

\begin{tabular}{lccc}
\hline & \multicolumn{3}{c}{ Nitrogen fertilization (N) } \\
& N 50 & N 100 & N 150 \\
\hline Species/cultivar (SP) & & & \\
Conni & 95 & 93 & 91 \\
Cynthia & 77 & 78 & 84 \\
Haga & 64 & 71 & 68 \\
Julia & 59 & 59 & 69 \\
Rasti & 38 & 42 & 45 \\
Center & 66 & 67 & 79 \\
Juliska & 73 & 80 & 76 \\
Koket & 60 & 58 & 55 \\
Näpsä & 56 & 59 & 57 \\
Mixture 1 & 82 & 80 & 75 \\
Mixture 2 & 79 & 85 & 77 \\
Mixture 3 & 61 & 58 & 55 \\
SEM & 2.8 & & \\
Source of variation & & & \\
N & & & \\
SP & & 0.74 & \\
N*SP & & $<0.001$ & \\
\hline
\end{tabular}

1) SEM same for all means 


\section{AGRICULTURAL AND FOOD SCIENCE IN FINLAND}

Virkajärvi, P. et al. Effect of fertilization, grass species and cultivar on sod production

Table 5. Effect of nitrogen fertilization and species/cultivar on the mineral content in dry matter of grass samples before lifting, 1992. Means of $\mathrm{N}$ levels and species/cultivar $(\mathrm{PP}=$ P. pratensis and $\mathrm{FR}=$ F. rubra $)$, standard error of means $(\mathrm{SEM})$ and $\mathrm{F}$ values in the analysis of variance ( $\mathrm{p}$ values).

\begin{tabular}{|c|c|c|c|c|c|c|c|c|c|}
\hline & $\mathrm{N}$ & $\begin{array}{ll}\mathrm{Ca} & \\
& \mathrm{g} \mathrm{b}\end{array}$ & $\mathrm{Mg}$ & $P$ & $\mathrm{Cu}^{\prime}$ & $\mathrm{Fe}^{2}$ & $\begin{array}{c}\mathrm{Mn}^{1} \\
\mathrm{mg} \mathrm{kg}^{-1}\end{array}$ & Mo & $\mathrm{Zn}$ \\
\hline $\begin{array}{l}\text { Mean } \\
N \text { fertilizt }\end{array}$ & 20.5 & 4.99 & 1.40 & 3.18 & 27.9 & 97.2 & 246.6 & 1.92 & 32.3 \\
\hline 50 & 16.5 & 5.22 & 1.34 & 2.78 & 32.2 & 108.4 & 292.1 & 2.14 & 33.7 \\
\hline 100 & 20.6 & 4.90 & 1.35 & 3.28 & 25.2 & 86.6 & 229.2 & 1.93 & 31.1 \\
\hline 150 & 24.6 & 4.85 & 1.51 & 3.49 & 26.1 & 96.5 & 218.6 & 1.68 & 32.2 \\
\hline SEM & 0.29 & 0.174 & 0.035 & 0.212 & - & - & - & 0.096 & 2.13 \\
\hline \multicolumn{10}{|c|}{ Species/cultivar (SP) } \\
\hline PP & 20.7 & 4.64 & 1.52 & 2.74 & 27.4 & 94.7 & 175.6 & 2.29 & 32.2 \\
\hline FR & 20.4 & 5.33 & 1.27 & 3.63 & 28.3 & 99.7 & 317.6 & 1.55 & 32.4 \\
\hline SEM & 0.23 & 0.142 & 0.028 & 0.099 & $\begin{array}{r}- \\
P \text { values }\end{array}$ & - & - & 0.078 & 1.74 \\
\hline \multicolumn{10}{|c|}{ Source of variation } \\
\hline N & 0.004 & 0.13 & 0.09 & 0.048 & 0.75 & 0.07 & 0.029 & 0.035 & 0.87 \\
\hline SP & 0.55 & 0.014 & $<0.001$ & $<0.001$ & 0.63 & 0.016 & $<0.001$ & $<0.001$ & 0.93 \\
\hline $\mathrm{N} * \mathrm{SP}$ & 0.98 & 0.45 & 0.37 & 0.96 & 0.21 & 0.13 & 0.45 & 0.21 & 0.68 \\
\hline
\end{tabular}

${ }^{1}$ Analysis of variance for $\log (\mathrm{x})$ transformation; no SEM presented

${ }^{2}$ Analysis of variance for $1 / x$ transformatiom; no SEM presented

were lower. In statistical analyses of the $\mathrm{K}$ concentration interaction was found between $\mathrm{N}$ fertilization and species/cultivar $(\mathrm{p}=0.017)$. Indeed, $\mathrm{N}$ fertilization increased the $\mathrm{K}$ concentration more in Festuca than in Poa, since the K concentrations in Poa were 20.0, 23.5 and $22.7 \mathrm{~g} \mathrm{~kg}^{-1}$ while in Festuca they were 17.7, 22.9 and $23.6 \mathrm{~g} \mathrm{~kg}^{-1}$ with $\mathrm{N}$ levels of 50,100 and $150 \mathrm{~kg} \mathrm{ha}^{-1}$, respectively (SEM $0.382 \mathrm{~g} \mathrm{~kg}^{-1}$ ).

The rooting ability of the sod is well seen in the green cover values of the following summer (Table 6). Nitrogen fertilization before lifting increased the green cover but the effect was dependent on the cultivar/mixture. 'Conni' and 'Rasti', which had high green cover values already with low $\mathrm{N}$, reacted only weakly or not at all to the increased N. On the contrary, 'Cynthia' and 'Näpsä', which had a low green cover at low $\mathrm{N}$, increased their green cover highly with increasing $\mathrm{N}$ levels. It must be noticed that the green cover of 'Näpsä' may be partly due to other species, since it had a very low botanical purity.
At the highest $\mathrm{N}$ level only 'Center', 'Koket' and 'Näpsä' failed to achieve the $80 \%$ level of green cover on average. Mixture 1, 'Rasti', 'Haga' and 'Julia' achieved a $90 \%$ green cover on average.

\section{Discussion}

\section{Effect of $\mathrm{N}$ fertilization}

Increasing $\mathrm{N}$ fertilization from $50 \mathrm{~kg}$ up to 150 $\mathrm{kg}$ ha- 1 had a positive effect on the general quality, as well as on the green cover before and after transplanting. Its positive effect on the number of tillers and the green cover in the year following transplanting was dependent on the species/cultivar. Nitrogen had a tendency to level off the differences between species/cultivars. The most striking phenomenon was that the effect of nitrogen fertilization was more important for green cover after transplanting the sod than 


\section{AGRICULTURAL AND FOOD SCIENCE IN FINLAND}

Vol. 6 (1997): 269-281.

before lifting. This may indicate the physical stress of sodding and point out the importance of vigour of the sod for successful transplanting. The observed green cover values before lifting generally exceeded the limit of good-quality turf (80\%; Härkönen et al 1991) with 100 and $150 \mathrm{~kg} \mathrm{ha}^{-1}$. The values dropped by nearly $20 \%$ after transplanting, less with higher $\mathrm{N}$, but the effect of $\mathrm{N}$ was dependent also on the species/ cultivar. The $80 \%$ green cover was reached only with $150 \mathrm{~kg} \mathrm{~N}$, with the exception of 'Conni', which exceeded the limit with $100 \mathrm{~kg} \mathrm{~N}$. Except 'Juliska', F. rubra cultivars did not reach the $80 \%$ limit even with the highest N. During the following season 'Conni' and 'Rasti' exceeded the $80 \%$ green cover limit with only $50 \mathrm{~kg} \mathrm{~N}$. With the highest N, only 'Näpsä' had a low green cover, which was due to its weak rooting. This kind of positive carry-over effect of moderate $\mathrm{N}$ dose on the turf quality was reported also by Cisar et al. (1992). In this trial the effect was partly due to increased vigour of sod before lifting (Table 3 ) and partly to increased $\mathrm{N}$ reserves of tillers (Table 5). Nitrogen may have accumulated also in the roots and in the soil of transplanted sod. If the plots had been uniformly fertilized with $\mathrm{N}$ during the summer after transplanting, which is a common practice, the carry-over effect may not have been detected so clearly.

The only negative effect of increasing $\mathrm{N}$ detected was increased thatch formation. Since its formation is a function of growth and decomposition (Waddington 1992), it is logical that N fertilization increased the thatch layer. A thick layer of thatch is harmful due to e.g. the slow infiltration rate of water. According to Beard (1973), a thatch layer more than 10-15 mm thick lowers the quality of turf. In this experiment, the $15 \mathrm{~mm}$ limit was almost reached with the $\mathrm{N}$ fertilization rate of $100 \mathrm{~kg} \mathrm{ha}^{-1}$. Generally, in this trial the thatch layer may have increased because of low $\mathrm{pH}$ and possible low microbial activity of the soil (Waddington 1992).

Since the experiment had only three replicates and the effects of $\mathrm{N}$ were analysed as main plot effects, there is a risk that some of the effects of $\mathrm{N}$ would not have been detected although
Table 6. Interaction between $\mathrm{N}$ fertilization and species/ cultivar on the green cover during mid-summer 1993. Species means within $\mathrm{N}$ fertilization levels, standard errors of means (SEM) and significances of F values in the analysis of variance.

\begin{tabular}{|c|c|c|c|}
\hline & \multicolumn{3}{|c|}{ Nitrogen fertilization (N) } \\
\hline & N 50 & N 100 & N 150 \\
\hline \multicolumn{4}{|l|}{ Species/cultivar (SP) } \\
\hline Conni & 83 & 91 & 86 \\
\hline Cynthia & 31 & 77 & 81 \\
\hline Haga & 62 & 81 & 90 \\
\hline Julia & 72 & 88 & 90 \\
\hline Rasti & 88 & 85 & 90 \\
\hline Center & 47 & 65 & 74 \\
\hline Juliska & 56 & 67 & 80 \\
\hline Koket & 47 & 58 & 77 \\
\hline Näpsä & 26 & 51 & 61 \\
\hline Mixture 1 & 62 & 84 & 92 \\
\hline Mixture 2 & 65 & 79 & 86 \\
\hline Mixture 3 & 75 & 68 & 89 \\
\hline SEM $^{1}$ & 5.9 & & \\
\hline Source of variation & \multicolumn{3}{|c|}{$P$ values } \\
\hline $\mathrm{N}$ & \multicolumn{3}{|c|}{0.010} \\
\hline SP & \multicolumn{3}{|c|}{$<0.001$} \\
\hline $\mathrm{N} * \mathrm{SP}$ & \multicolumn{3}{|c|}{0.002} \\
\hline
\end{tabular}

1) SEM same for all means.

such an effect could have existed. Such an error may be true with underground biomass and rooting. These effects were not statistically significant in this experiment. There was only a tendency for $\mathrm{N}$ to lower the underground biomass, although it is a rather common phenomenon (e.g. Nelson 1984, Turner and Hummel 1992). Similarly, moderate $\mathrm{N}$ is known to promote rooting (Turner and Hummel 1992), but high doses may impair rooting if the sod is forced to grow fast and its root system and carbohydrate levels are thus low (Beard 1973). In this experiment, the $\mathrm{N}$ fertilization rates used were moderate, and probably the utilization of $\mathrm{N}$ was low, which may also explain the fact that the effect did not occur in this experiment. Furthermore, in Finland high $\mathrm{N}$ is often observed to increase the over-wintering risks especially in $F$. rubra and A. capillaris (Niemeläinen and Huusela-Veistola 1991). This 


\section{AGRICULTURAL AND FOOD SCIENCE IN FINLAND}

\section{Virkajärvi, $P$. et al. Effect of fertilization, grass species and cultivar on sod production}

was not observed in this experiment (based on green cover and general observations of overwintering diseases).

The observed $\mathrm{N}$ contents of herbage were low. Even with the highest $\mathrm{N}$ rate, the $\mathrm{N}$ content did not reach the level suggested by Beard (1973; $30-60 \mathrm{~g} \mathrm{~kg}^{-1}$ ) and Jones (1980; optimum 27. 5$35 \mathrm{~g} \mathrm{~kg}^{-1}$ ). A reason for this could be the low utilisation of given N. Precipitation in May, June and July was low compared with long-term values (Table 2). After the first application of $\mathrm{N}$ there was no rain in three weeks and the trial got only irrigation $(2 \times 15 \mathrm{~mm})$. The drought could be seen also in the original green cover values, which were assessed weekly. Also the high thatch formation could have lowered the utilisation of $\mathrm{N}$ (Waddington 1992). After transplantation there was immediately sufficient rainfall. The low utilisation may partly explain the fact that increasing $\mathrm{N}$ fertilization from $100 \mathrm{~kg} \mathrm{ha}^{-1}(+10 \mathrm{~kg}$ in PK compound fertilizer) to $150 \mathrm{~kg}(+10 \mathrm{~kg}$ in PK compound fertilizer) affected positively the Festuca cultivars which generally thrive with low N (Beard 1973, Niemeläinen et al. 1991). The optimum $\mathrm{N}$ level was dependent on the cultivar within species, too. The observed results are in accordance with the recommendation of $120 \mathrm{~kg}$ ha $^{-1} \mathrm{~N}$ for Poa/Festuca sod in Finland (Raininko 1977).

\section{Species, cultivar and mixture}

Species, cultivar and mixture affected all measured variables except for thatch formation. The differences between cultivars were greater after transplanting than before lifting and also greater than in official cultivar trials in Finland (Järvi et al. 1995). The effect of subplot (species/cultivar) could not be explained only by grouping species, since there were clear differences between cultivars within species, too. This was true despite that all selected cultivars had succeeded well in trials in Finland by the time the trial was established (Niemeläinen 1990). With few ex- ceptions - 'Näpsä' and partly 'Cynthia' - green cover before lifting was a reasonable predictor for the green cover in the following season.

As expected, the P. pratensis cultivars used suited better for sod production than the cultivars of $F$. rubra. 'Conni' was one of the most suitable cultivars with almost any measured parameter. 'Cynthia' and 'Haga' reacted strongly to the increasing $\mathrm{N}$.

The F. rubra cultivars may have suffered from an unidentified reason during 1992 when growing on peat bog since their results were ranked generally poorer than those of $P$. pratensis even before lifting. However, 'Juliska' succeeded well in this trial. The low ranking of 'Center' is not in accordance with other Finnish trials (Järvi et al. 1995, Taivalmaa 1995). The reason for this remains obscure, since 'Center' was ranked low already before lifting, except for tiller density. Although 'Näpsä' had a good quality before lifting, it did not suit for sod production because of weak rooting and thus low tolerance against lifting and transplanting. 'Koket' and 'Näpsä' reacted strongly to the increasing $\mathrm{N}$.

A. capillaris 'Rasti' had a high green cover, a high tiller density and a low reaction to N. On the contrary, it had the lowest tearing force tolerance in this trial. If the tolerance against handling is estimated by tearing force per width $(\mathrm{kg}$ $\mathrm{cm}^{-1}$ ), the obtained value of 'Rasti', $1.8 \mathrm{~kg} / \mathrm{cm}$, is satisfactory compared to the lower critical values given by Beard (1973) and Shildrick (1982): 1.87 and $1.11 \mathrm{~kg} / \mathrm{cm}$, respectively. Generally, the high values obtained in this study are partly due to the two years age of the turf. The tearing force of 'Rasti' increased almost by $40 \%$ when $20 \%$ of $F$. Rubra was included in the seed mixture (Mixture 3).

$P$. pratensis and $F$. rubra mixtures succeeded well with rather small differences. This kind of mixtures are basic products in sod marketing, since they suit well for different purposes and soil conditions. The results emphasize the importance of cultivar selection for sod production in order to achieve maximum performance of transplanted sod. 


\section{AGRICULTURAL AND FOOD SCIENCE IN FINLAND}

Vol. 6 (1997): 269-281.

\section{Production on Valkeasuo peat bog}

In general, the greatest difficulties in sod production on a peat bog were caused by small pieces of undecomposed timber which tore the sod into pieces during the lifting process. Thus, the production areas must be chosen carefully before preparing the seedbed. The humus content of $15 \%$ (SD $6.8 \%$ ) seemed to be at the upper limit due to the sponginess of the soil which endangers the lifting process. It must also be noted that the final use of the sod sets limits for the humus content. According to the quality assesment of sport turfs, a humus content of $3-6 \%$ is ranked as highest. A humus content of $10-20 \%$ will get half of the maximum points (Lahdensuo 1993). The depth of peat layer before starting the experiment was $15 \mathrm{~cm}$ (SD 6.9). This is somewhat higher than the average for Valkeasuo after harvesting the peat, $10 \mathrm{~cm}$, reported by Eronen (1996). The observation of Eronen (1996) is important since it means that, on average, after harvesting the peat, the soil is then classified as mineral soil.

Despite the infertility of the soil, the mineral contents of the herbage samples, includind the high $\mathrm{Cu}$ concentration, were within normal range according to e.g. Jones (1980). The tiller number and the green cover values were equal to those observed in trials on more common soil types (Paatela and Järvinen 1994, Järvi et al. 1995).

The botanical purity was high compared with e.g. the sport turfs in Finland (Erlund 1991, Lahdensuo 1993). The abundance of dicotylendons or $P$. апnua was extremely low. This supports the hypothesis that the absence of seed bank of weeds on peat bogs immediately after harvesting the peat can be utilized.

\section{Conclusions}

Sod production is possible on peat bogs that resemble Valkeasuo. The soil must be clear from timber. Absence of weeds is an advantage. Clear differences between species as well as between cultivars within species exist in both production and in transplantation properties. Increasing $\mathrm{N}$ fertilization from 50 to 100 and $150 \mathrm{~kg} \mathrm{ha}^{-1}$ improved the most important features of sod, but the reaction was in many cases dependent on the species and the cultivar. The drought in the harvesting year must be considered when applying the results in practice.

Acknowledgements. The work was supported by the Agricultural Research Centre and the Finnish Peat Cultivation Society. The authors wish to thank Dr. O. Niemeläinen for help and comments in planning the experiment and preparing the manuscript. M. Laasonen, P. Heikkinen, L. Sallinen and M. Virkajärvi are acknowledged for excellent technical assistance. J. Pesonen (Karjalan Nurmi) carried out the harvesting of the sod.

\section{References}

Aitchison, J. 1986. The statistical analysis of compositional data. London. 405 p.

Beard, J.B. 1973. Turfgrass: science and culture. Englewood Cliffs, N.J. USA. 658 p.

Cisar, J.L., Snyder, G.H. \& Swanson, G.S. 1992. Nitrogen, phosphorus and potassium fertilization for Histosol grown St. Augustinegrass sod. Agronomy Journal 84, 3: 475-479.

CYTEL Software Corporation. 1995. StarXact 3 For Windows, Statistical Software for Exact Nonparametric
Interference, User Manual. Cambridge. 758 p.

Erlund, P. 1991. Urheilukenttien nurmikoiden laatututkimus 1990. In: Erlund, P. \& Lahdensuo, J. (eds.) Urheilukenttien nurmikoiden laatututkimus 19891991. Opetusministeriō. Liikuntapaikkarakentamisen raportti. p. 1-69.

Eronen, T. 1996. Valkeasuon turvetuotantoalueen jälkikăyttö. Tohmajärven kunta, Valkeasuo-projektin vuosiraportti 1995. $37 \mathrm{p}$.

Härkőnen, E., Niemelăinen, O. \& Huusela-Veistola, E. 


\section{AGRICULTURAL AND FOOD SCIENCE IN FINLAND}

\section{Virkajärvi, P. et al. Effect of fertilization, grass species and cultivar on sod production}

1991. Englanninraiheinä nurmikon perustamisessa Suomessa. Maatalouden tutkimuskeskus, Tiedote 17/ 91. $27 \mathrm{p}$.

Heikkilă 1990. Kun turve on nostettu. In: Suosta suomalaista elämää. Vapo. Jyväskylä. 94 p. 78-83.

Huusela-Veistola, E., Niemeläinen, O. \& Huhta, H. 1991. Lajikkeen, lannoituksen ja leikkuun vaikutus niittynurmikka-natanurmikon menestymiseen. Maatalouden tutkimuskeskus, Tiedote 13/91. 33 p.

Jårvi, A., Kangas, A., Mustonen, L., Salo, Y., Talvitie, H., Vuorinen, M. \& Măkelā, L. 1995. Virallisten lajikekokeiden tuloksia 1987-1994. Maatalouden tutkimuskeskus, Tiedote 2/95 $126 \mathrm{p}$.

Jones, J.R. Jr. 1980. Turf analysis. Golf Course Manage 48: 29-32.

Koch, G.G. 1970. The use of non-parametric methods in the statistical analysis of complex split-plot experiment. Biometrics 26: 105-128.

- , Amara, L.A., Stokes, M.E. \& Gillings, D.B. 1980. Some views on parametric and non-parametric analysis of repeated measurements and selected bibliography. International Statistical Review 48: 249-265.

Lahdensuo, J. 1993. Urheilukenttien nurmikoiden laatuluokitus. Opetusministeriö, Liikuntapaikkajulkaisu 40. $47 \mathrm{p}$.

Nelson, S.H. 1984. Response of Kentucky bluegrass, Poa pratensis L., to amount and frequency of nitrogen application. Canadian Journal of Plant Science 64: 369-374.

Niemeläinen, O. 1990. Tuloksia virallisesta nurmikkoheinien lajiketestaustoiminnasta. In: Niemeläinen, O. \& Huusela-Veistola, E. (ed.). Nurmikkotutkimuspäivä 8.8.1990. MTTK, Jokioinen. p. 11-22.
- \& Huusela-Veistola, E. 1991. Typpilannoituksen vaikutus niittynurmikka-, nurmirölli-, puisto- ja punanatanurmikon kasvuun ja keståvyyteen. Maatalouden tutkimuskeskus, Tiedote 12/91. 38 p.

- , Huusela-Veistola, E., Nissinen, O., Ahvenniemi, P., Laurila, A. \& Ravantti, S. 1991. Lannoituksen ja leikkuukorkeuden vaikutus nata- ja niittynurmikkalajikkeiden peittåvyyteen ja kestävyyteen nurmikossa. Maatalouden tutkimuskeskus, Tiedote 15/91. 35 p.

Paatela, J. \& Jărvinen, E. 1994. Golfkenttien viherpeitetutkimus. Opetusministeriö, Liikuntapaikkajulkaisu 50. $175 \mathrm{p}$.

Raininko, K. 1977. Kaunis, kestãvă nurmikko. Puutarhaliiton opaskirja no 25, julkaisu no 210.98 p.

Rosenthal, R. \& Rosnow, R.L. 1985. Contrast analysis, focused comparisons in the analysis of variance. Cambridge. $107 \mathrm{p}$.

SAS 1991. SAS systems for linear models. 3rd ed., Cary, NC: SAS Institute Inc. 329 p.

- 1992. SAS Technical Report P-229, SAS/STAT Software: Changes and Enchancements, Release 6.07, Cary, NC: SAS Institute Inc. 620 p.

Shildrick, J.P. 1982. Mixtures and seed rates for sod production. Journal of Sports Turf Research Institute 58: 76-95.

Taivalmaa, S.-L. 1995. Heinălaji nurmikkoon kåytön perusteella. Koetoiminta ja käytäntö 52: 57.

Turner, T.R. \& Hummel, N.W., Jr. 1992. Nutritional requirements and fertilization. In: Waddington, D.V. et al. (eds.) Turfgrass. Madison, USA. p. 385-439.

Waddington, D.V. 1992. Soils, soil mixtures and soil amendments. In: Waddington, D.V. et al. (eds.) Turfgrass. Madison, USA. p. 331-383. 
Vol. 6 (1997): 269-281.

\title{
SELOSTUS
}

\section{Typpilannoituksen, kasvilajin ja lajikkeen vaikutus siirtonurmikon tuotanto- ominaisuuksiin Valkeasuon turvetuotannon jättöalueella}

\author{
Perttu Virkajärvi, Harri Huhta ja Hannu Tuuri \\ Maatalouden tutkimuskeskus
}

Siirtonurmikon tuotantomahdollisuuksia tutkittiin Tohmajärven Valkeasuolla vuosina 1990-1993 osana polttoturvesoiden jälkikäyttöä selvittävää projektia. Tutkimuksen päämääränä oli selvittää typpilannoituksen sekä kasvilajien ja lajikkeiden vaikutusta nurmikon kasvattamiseen ja siirrettävän nurmikon laatuun. Typpilannoituksen määrä oli joko 50,100 tai $150 \mathrm{~kg}$ ha $^{-1}$. Niittynurmikoita edustivat lajikkeet Conni, Cynthia, Haga ja Julia, punanatoja Center, Juliska, Koket ja Näpsä sekä nurmirölliä Rasti. Puhtaiden lajikkeiden lisäksi kylvettiin niittynurmikka-punanata- ja nurmirölli-punanataseoksia edustamaan kaupallisia siirtonurmikkotuotteita.

Typpilannoituksen nostaminen $50 \mathrm{~kg}$ :sta $150 \mathrm{~kg}$ :n paransi nurmikon yleisarvosanaa (väri, tiheys, yhtenäisyys, rikkaruohoisuus) ja viherpeittävyyttä sekä ennen nostoa että asennuksen jälkeen. Typpilannoi- tus vaikutti eri lajikkeilla eri tavalla versojen lukumäärään ja viherpeittävyyteen asennusta seuraavana vuotena. Karikekerroksen paksuuntuminen oli typpilannoituksen nostamisen ainoa negatiivinen seuraus. Kasvilaji tai lajike vaikutti kaikkiin nurmikon ominaisuuksiin karikekerroksen paksuutta lukuunottamatta. Maapohjassa esiintyvät puunkappaleet aiheuttivat laattojen viottumista noston aikana. Koealueen humuspitoisuus oli noston kannalta ylärajoilla. Huolimatta maapohjan karuudesta oli nurmikosta mitatut Ca-, K-, Mg-, P-, Cu-, Fe-, Mn-, Mo- ja Zn-pitoisuudet normaaleissa rajoissa. Rikkakasveja esiintyi erittäin vähän.

Siirtonurmikon tuotanto onnistuu koealueen kaltaisilla suopohjilla. Laji- ja lajikevalinta on keskeinen seikka siirtonurmikon tuotannossa. Sopiva typpilannoitustaso riippuu lajikkeesta. 